\title{
Efficacy of Ageratum conyzoides extracts against Giardia duodenalis trophozoites: an experimental study
}

\author{
Ai-rada Pintong ${ }^{1}$, Jiraporn Ruangsittichai', Sumate Ampawong ${ }^{2}$, Kanthinich Thima ${ }^{3}$, Patchara Sriwichai ${ }^{1}$, \\ Narumon Komalamisra ${ }^{1}$ and Supaluk Popruk ${ }^{3^{*}}$ (i)
}

\begin{abstract}
Background: Giardia duodenalis causes giardiasis in humans, particularly in developing countries. Despite the availability of treatments, resistance to some of the commercial anti-Giardia drugs has been reported in addition to their harmful side effects. Therefore, novel treatments for giardiasis are required. In this study, we aimed to assess the in vitro activity of crude extracts of Ageratum conyzoides against G. duodenalis trophozoites.

Methods: Plants were classified into three groups based on their flower colors: white (W), purple (P), and whitepurple (W-P). Plants were separately cut into leaf ( $(\mathrm{L})$ and flower $(\mathrm{F})$ parts. Changes in internal organelle morphology of trophozoites following exposure to crude extracts were assessed using transmission electron microscopy (TEM). In subsequent experiments, efficacy of the most active essential oils from crude extracts [half maximal inhibitory concentrations $\left(\mathrm{I}_{50}\right) \leq 100 \mu \mathrm{g} / \mathrm{mL}$ ] against $\mathrm{G}$. duodenalis trophozoites was tested. In vitro anti-Giardia assays using essential oils were performed in the same way as those performed using crude extracts.

Results: LW-P and FP extracts showed high activity $\left(\mathrm{IC}_{50} \leq 100 \mu \mathrm{g} / \mathrm{mL}\right)$ against $\mathrm{G}$. duodenalis trophozoites, with $I C_{50} \pm S D$ values of $45.67 \pm 0.51$ and $96.00 \pm 0.46 \mu \mathrm{g} / \mathrm{mL}$, respectively. In subsequent experiments, $I_{50} \pm S D$ values of LW-P and FP essential oils were $35.00 \pm 0.50$ and $89.33 \pm 0.41 \mu \mathrm{g} / \mathrm{mL}$, respectively. TEM revealed the degeneration of flagella and ventral discs of $G$. duodenalis trophozoites following exposure to crude extracts.

Conclusion: Crude LW-P and FP extracts of A. conyzoides showed the highest activity against G. duodenalis. Exposure to crude extract induced changes in the flagella and ventral discs of G. duodenalis trophozoites, which play important roles in attachment to the surface of mucosal cells. Our results suggest that the tested extracts warrant further research in terms of their efficacy and safety as giardiasis treatment.
\end{abstract}

Keywords: Giardia duodenalis, Ageratum conyzoides, Crude extract, Organelles

\section{Background}

Giardia duodenalis (syn. G. lamblia or G. intestinalis) is a common enteric protozoan that causes giardiasis in humans and animals. The greatest burden of giardiasis worldwide is found in developing countries, where poor

\footnotetext{
* Correspondence: supaluk.pop@mahidol.ac.th

${ }^{3}$ Department of Protozoology, Faculty of Tropical Medicine, Mahidol University, Ratchawithi Road, Ratchathewi, Bangkok 10400, Thailand Full list of author information is available at the end of the article
}

sanitary conditions and ineffective water treatment are common [1]. Nearly 280 million people worldwide are infected annually [2-5]. In Thailand, the prevalence of giardiasis in humans has been reported to be $0.4-37.7 \%$ in different populations and locations [6-20]. Giardiasis leads to mortality and morbidity in the elderly, travelers, and patients with immune system defects [21, 22]. Giardiasis symptoms vary from asymptomatic cases to chronic diarrhea [23]. In cases of severe infection in

(c) The Author(s). 2020 Open Access This article is licensed under a Creative Commons Attribution 4.0 International License, which permits use, sharing, adaptation, distribution and reproduction in any medium or format, as long as you give appropriate credit to the original author(s) and the source, provide a link to the Creative Commons licence, and indicate if changes were made. The images or other third party material in this article are included in the article's Creative Commons licence, unless indicated otherwise in a credit line to the material. If material is not included in the article's Creative Commons licence and your intended use is not permitted by statutory regulation or exceeds the permitted use, you will need to obtain permission directly from the copyright holder. To view a copy of this licence, visit http://creativecommons.org/licenses/by/4.0/. The Creative Commons Public Domain Dedication waiver (http://creativecommons.org/publicdomain/zero/1.0/) applies to the data made available in this article, unless otherwise stated in a credit line to the data. 
children, it may lead to malnutrition and affect mental and physical development [24]. Giardiasis in patients with HIV/AIDS can lead to acute or chronic diarrhea [25-28].

Partial failure in giardiasis treatment due to drug resistance has been reported to occur in endemic areas [1]. Metronidazole is the first-line treatment for giardiasis, although adverse side effects have been reported; metallic taste, headache, dry mouth and, to a lesser extent, nausea, glossitis, urticaria, pruritus, and dark colored urine $[29,30]$. Moreover, carcinogenic, teratogenic, and embryogenic properties of metronidazole have been reported [31, 32]. Therefore, search for novel agents to treat giardiasis has accelerated.

Plant products, such as crude extracts and essential oils, are potential alternative agents being explored for the development of novel antimicrobial drugs. One of their advantages is that they have low toxicity in mammalian cells [33]. Plants belonging to the family Compositae show medicinal properties and contain numerous compounds, some of which may have potential as novel drug sources [34, 35]. Moreover, crude extracts and compounds isolated from these plants have shown antiprotozoal activity [35]. Some Compositae species, including Chromolaena odorata and Tithonia diversifolia, have been reported to show antimalarial activities and have been used in traditional medicine [36-38].

Ageratum conyzoides is a common annual herbaceous weed belonging to the family Compositae and has a long history of traditional medicinal use [39]. It is a tropical plant commonly found in Central America, the Caribbean, Southeast Asia, South China, India, West Africa, Australia, and South America [40, 41]. In many countries, it is utilized in folk medicine, such as that for skin diseases, wound healing, diarrhea, and navel pain in $\mathrm{Ni}$ gerian children [41-43]. Phytochemical investigations of this plant have revealed pharmacological and insecticidal properties conferred by a number of its secondary metabolites [41, 44]. Whole plant extracts have shown inhibitory action against bacteria and mosquitoes [45]. Aqueous and ethanolic extracts of $A$. conyzoides leaves were tested for their activity against the intestinal worm Heligmosomoides bakeri, with ethanolic extracts being particularly efficient against this worm [46]. However, no studies thus far have tested the properties of this plant against pathogenic intestinal protozoa, such as $G$. duodenalis.

Therefore, in this study, we aimed to investigate the antiprotozoal properties of A. conyzoides extracts. Efficacy of six types of crude extracts, including those from leaves of white (LW), purple (LP), or white-purple flowered (LW-P) plants and flowers of white
(FW), purple (FP), and white-purple flowered (FWP) plants as well as two types of essential oils from LW-P and FP plants, was tested against G. duodenalis trophozoite. Changes in internal organelle morphology of trophozoites following exposure to crude extracts were assessed using transmission electron microscopy (TEM). Our result demonstrated the efficacy and organelle targets of $A$. conyzoides extracts against G. duodenalis and provided basis for the development of novel therapeutic agents against giardiasis in the future.

\section{Methods \\ Plant collection}

We reviewed the characteristics of $A$. conyzoides such as flower, leaf, stem, and areas of distribution. In March 2016-2017, we visited wasteland in Chiang Khong district in Chiang Rai province $\left(20^{\circ} 15^{\prime} 36^{\prime \prime} \mathrm{N}\right.$ $100^{\circ} 24^{\prime} 24^{\prime \prime}$ E) of Thailand, where this plant commonly grows. This plant is a type of weed that can grow anywhere. The wastelands were owned by residents of villages nearby. The owners readily agreed to plant collection because this is a weed. In the wild, flowers of three colors-white (W), purple (P), and white-purple (W-P)-were observed. They were identified plant species by Mrs. Parinyanoot Klinratana, a researcher at the Department of Botany, Faculty of Science, Chulalongkorn University, Thailand. The results represented that the flowers of three colors were the same plant. Voucher specimens are deposited in the Professor Kasin Suvatabhandhu Herbarium (Number 015854), Department of Botany, Faculty of Science, Chulalongkorn University, Thailand.

\section{Plant extractions \\ Crude extractions}

Fresh plants (LW, LP, LW-P, FW, FP, and FW-P) (Fig. 1) were dried at $60^{\circ} \mathrm{C}$ in an oven for 7 days. The samples were stored in a cool and dry place. Dried plant material was pulverized and macerated using absolute ethanol as a solvent. The extract was filtered using Whatman filter paper $(0.45 \mu \mathrm{m}$ diameter $)$, and solvent was removed using rotary vacuum evaporation (Heidolph, Germany). All dried crude extracts were stored at $4{ }^{\circ} \mathrm{C}$ until further use.

\section{Essential oils}

Fresh plants were suspended in distilled water and subjected to hydrodistillation for $3 \mathrm{~h}$. Sodium sulfate $\left(\mathrm{Na}_{2} \mathrm{SO}_{4}\right)$ was used to remove any trace of water from the essential oils, which were stored in dark glass vials at $4{ }^{\circ} \mathrm{C}$ until further use. 

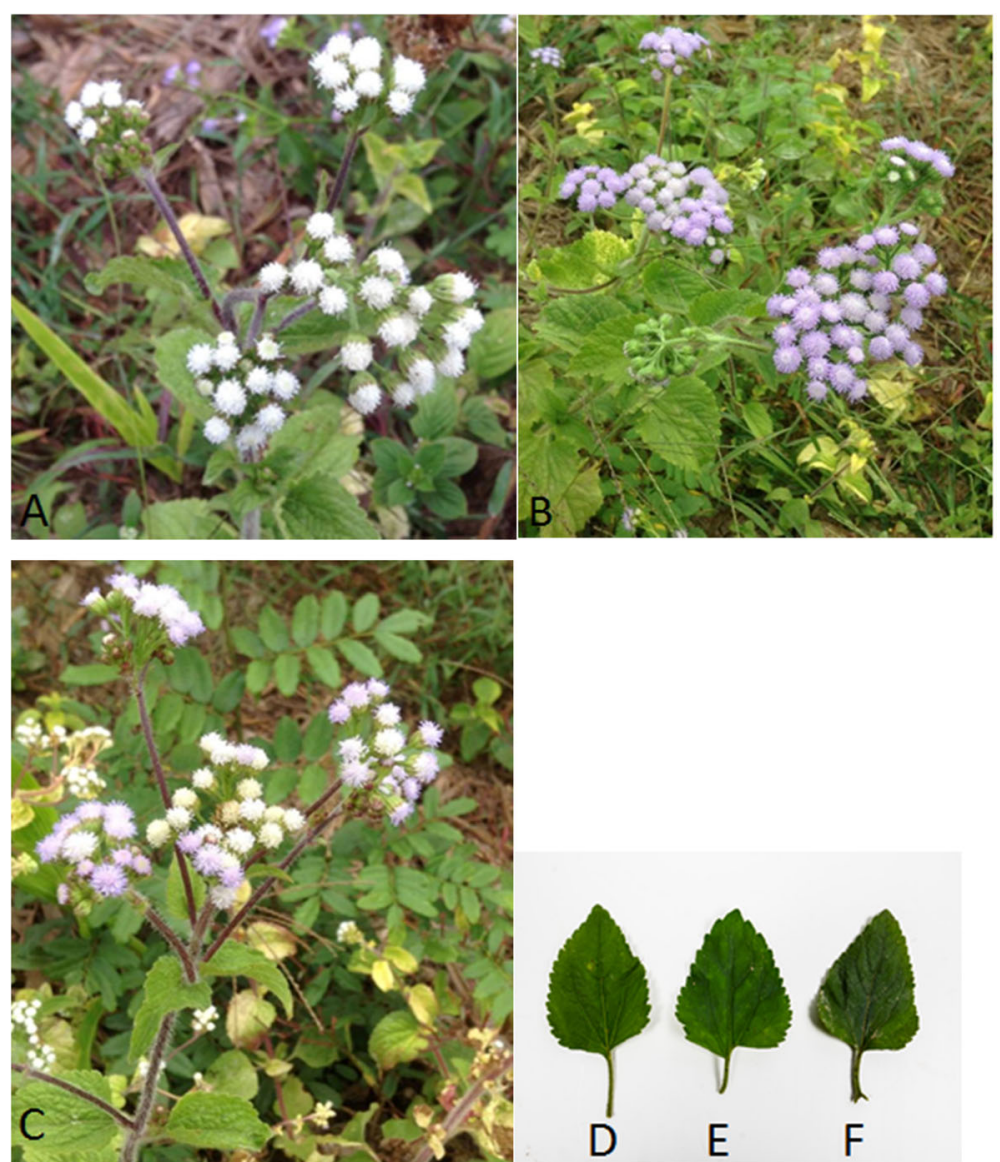

Fig. 1 Different organs of Ageratum conyzoides: flowers of white flowered (a), flowers of purple flowered (b), flowers of white-purple flowered (c), leaves of white flowered (d), leaves of purple flowered (e), and leaves of white-purple flowered (f) plants

\section{G. duodenalis culture}

Modified TYI-S-33 medium (Trypticase-yeast extractiron-serum medium) was used for culturing G. duodenalis trophozoites modified by Keister's modification [47]. Initially, G. duodenalis trophozoites were kept and maintained in the Department of Protozoology, Faculty of Tropical Medicine, Mahidol University. G. duodenalis trophozoites were grown in vitro under anaerobic conditions at $37^{\circ} \mathrm{C}$. After incubation for 24 $h$, cell growth and viability were examined every 2 days using inverse microscopy. Trophozoite-stage cultures were harvested once they reached the log phase (2-3 days), placed on ice for $10 \mathrm{~min}$, and centrifuged (3500 rpm, at $4{ }^{\circ} \mathrm{C}$ for $7 \mathrm{~min}$ ). Trophozoites were counted using a hemocytometer and used for subsequent experiments.

\section{In vitro anti-Giardia assay}

Each crude extract was dissolved in 100\% dimethyl sulfoxide (DMSO), and two-fold serial dilutions were made. Notably, $100 \%$ growth without extracts (non-treated) and $0.25 \%$ DMSO were used as negative control. Metronidazole (Sigma-Aldrich, St Louis, MO) without any extracts was used as positive control. Culture medium alone was used as a blank. For test groups, various concentrations of each crude extract were dissolved in 100\% DMSO. Test samples along with negative and positive controls and the blank were added to 96-well microplates. Trophozoites at a density of $5 \times 10^{4}$ were added to each well to make the final volume of $100 \mu \mathrm{L}$. The final concentration of DMSO was $0.25 \%$ in test groups (the final volume of $100 \mu \mathrm{L}$ in 96-well microplates) and this concentration did not affect trophozoites (negative control). All experiments were performed in triplicates. The plates were sealed and incubated at $37^{\circ} \mathrm{C}$ for $24 \mathrm{~h}$ under anaerobic conditions in 2.5-L Pack-Rectangular Jars (Mitsubishi Gas Chemical, Tokyo, Japan). After incubation for $24 \mathrm{~h}, 100 \mu \mathrm{L}$ BacTiter-Glo ${ }^{\text {ru }}$ Microbial Cell Viability Assay fluid was added to each well before trophozoite viability was recorded using luminescence. Percentage cell viability at each concentration of crude extract was determined using the following formula: 


$$
\text { \%inhibition }=100-\% \text { trophozoites that survived }
$$

The half maximal inhibitory concentration $\left(\mathrm{IC}_{50}\right)$ was defined as the concentration of crude extract required to inhibit cell growth by $50 \%$. The criteria used for defining the degree of activity of plant extracts in terms of inhibiting Giardia seemed to vary across test groups. Therefore, the following criteria proposed by Amaral et al. were used [48]: $\mathrm{IC}_{50} \leq 100 \mu \mathrm{g} / \mathrm{mL}=$ highly active; $100<$ $\mathrm{IC}_{50} \leq 250 \mu \mathrm{g} / \mathrm{mL}=$ active, $\quad 250<\mathrm{IC}_{50} \leq 500 \mu \mathrm{g} / \mathrm{mL}=$ moderately active; $\mathrm{IC}_{50} \geq 500 \mu \mathrm{g} / \mathrm{mL}=$ inactive.

For subsequent experiments, the most active essential oils from crude extracts $\left[\mathrm{IC}_{50} \leq 100 \mu \mathrm{g} / \mathrm{mL}\right.$ (highly active)] were tested against G. duodenalis trophozoites. Essential oils from LW-P and FP plants were the most active. Next, in vitro anti-Giardia assays using essential oils were performed in the same way as those performed using crude extracts.

\section{Gas chromatography and mass spectroscopy (GC-MS) analysis}

LW-P and FP essential oils were analyzed using an Agilent Technologies $6980 \mathrm{~N}$ GC chromatograph, equipped with a HP-5 MS capillary column $(30 \mathrm{~m} \times 0.25 \mathrm{~mm} \times$ $0.25 \mu \mathrm{m})$ and interfaced to a mass spectrometer $(5973$ $\mathrm{N})$. Helium was used as the carrier gas in the GC system, and the column temperature was increased by $7^{\circ} \mathrm{C} / \mathrm{min}$ between $100^{\circ} \mathrm{C}$ and $300^{\circ} \mathrm{C}$. Samples were injected using the split mode, and the total run time was $46 \mathrm{~min}$. MS conditions were measured at $70 \mathrm{eV}$ at a mass range of $\mathrm{m} / \mathrm{z}$ 50-600 amu. Components were identified based on peaks in gas chromatographic analyses and comparison of mass spectra with computer searches using Wiley 10th edition/NIST 2014 Combined Library.

\section{Ultrastructure analysis}

TEM was performed to determine the ultrastructure of G. duodenalis trophozoites following exposure to crude extracts. Trophozoites treated with crude extracts leading to $50 \%$ cell death, $100 \%$ cell growth (negative control group), and $0 \%$ cell growth (positive control group) were fixed in $2.5 \%$ glutaraldehyde and $1 \%$ osmium tetroxide, dehydrated in graded ethanol, infiltrated in graded resin (LR white; EMS, USA), embedded in pure resin, and polymerized at $65^{\circ} \mathrm{C}$ in an oven for $48 \mathrm{~h}$. The specimens were cut into $100-\mathrm{nm}$ thick slices and stained with lead citrate and uranyl acetate. Using TEM (model HT7700, Hitachi, Japan), changes in ultrastructure were examined in at least 10 fields (300 Giardia/group), focusing on the nuclei, flagella, ventral discs, peripheral vesicles, chromatin, and shape, and percentage of abnormal cells per field was calculated $(\times 0.7 \mathrm{~K}$ magnification).

\section{Statistical analysis}

Descriptive analysis (percentages) was used to describe sample data in this study. The mean $\mathrm{IC}_{50} \pm$ standard deviations (SD) values for the crude extracts, essential oils and metronidazole were determined using SPSS version 18.0 (IBM, Armonk, NY).

\section{Results}

Yields of six types of crude extracts were 17.41, 11.44, and $12.15 \%$ from LW, LP, and LW-P, respectively, and $10.30,12.24$, and $10.95 \%$ from FW, FP, and FW-P, respectively. After $24 \mathrm{~h}$ of treatment, $\mathrm{IC}_{50} \pm \mathrm{SD}$ values were $130.00 \pm 0.30$ (active), $463.08 \pm 0.87$ (moderately active), and $45.67 \pm 0.51$ (highly active) $\mu \mathrm{g} / \mathrm{mL}$ from $\mathrm{LW}$, LP, and LW-P, respectively, and $166.00 \pm 0.45$ (active), $96.00 \pm 0.46$ (highly active), and $207.00 \pm 0.50$ (active) $\mu \mathrm{g} / \mathrm{mL}$ from FW, FP, and FW-P, respectively, and the values were dose dependent. Essential oil yields from LW-P and FP were low at 0.19 and $0.16 \%$, respectively. $\mathrm{IC}_{50} \pm \mathrm{SD}$ values of the $\mathrm{LW}-\mathrm{P}$ and $\mathrm{FP}$ essential oils were $35.00 \pm 0.50$ (highly active) and $89.33 \pm 0.41$ (highly active) $\mu \mathrm{g} / \mathrm{mL}$, respectively.

Chemical constituents of LW-P and FP essential oils were 32 and 35, respectively. Primary chemical components were chromene groups (precocene I, precocene II, and 6-vinyl-7-methoxy-2,2-dimethylchromene), followed by sesquiterpenes ( $\beta$-caryophyllene, $\alpha$-caryophyllene, germacrene $\mathrm{D}$, copaene, caryophyllene oxide, and $\beta$ bourbonene) and monoterpenes ( $\alpha$-pinene, camphene, $\beta$-pinene, limonene, and endo-bornyl acetate) (Table 1). These three chemicals represented $80 \%$ of the components found in each essential oil.

Giardia trophozoites exposed to crude extracts, including LW-P and FP, showed ultrastructural changes compared with normal architecture when examined using TEM (Fig. 2a and b; arrow),

\section{Discussion}

Several methods have been used to evaluate the cytotoxicity and viability of cells, including dye exclusion (trypan blue), colorimetric assays (3-[4,5-dimethylthiazol-2yl]-2,5 diphenyl tetrazolium bromide), fluorometric 
Table 1 The chemical constituents and components of LW-P and FP essential oils of A. conyzoides, expressed as percent of total area

\begin{tabular}{|c|c|c|c|c|}
\hline \multirow[t]{2}{*}{ No. } & \multirow[t]{2}{*}{ Components } & \multirow[t]{2}{*}{$\begin{array}{l}\text { Essential oils } \\
\text { groups }\end{array}$} & \multicolumn{2}{|c|}{$\begin{array}{l}\text { Plant types } \\
\text { (number of constituents) }\end{array}$} \\
\hline & & & LW-P (32) & FP (35) \\
\hline 1 & Precocene I & Chromene & 48.04 & 42.86 \\
\hline 2 & $\beta$-caryophyllene & sesquiterpenes & 20.60 & 21.49 \\
\hline 3 & Precocene II & Chromene & 12.81 & 14.45 \\
\hline 4 & a-caryophyllene & sesquiterpenes & 2.51 & 4.09 \\
\hline 5 & Germacrene D & sesquiterpenes & 2.87 & 3.46 \\
\hline 6 & Copaene & sesquiterpenes & 0.21 & 0.08 \\
\hline 7 & Caryophyllene oxide & sesquiterpenes & 0.58 & 0.43 \\
\hline 8 & 6-vinyl-7-methoxy-2,2-dimethylchromene & Chromene & 0.17 & 0.17 \\
\hline 9 & a-pinene & monoterpenes & & 0.06 \\
\hline 10 & Camphene & monoterpenes & & 0.93 \\
\hline 11 & $\beta$-pinene & monoterpenes & & 0.05 \\
\hline 12 & Limonene & monoterpenes & & 0.14 \\
\hline 13 & $\beta$-bourbonene & sesquiterpenes & 0.14 & \\
\hline 14 & endo-bornyl acetate & monoterpenes & 0.17 & \\
\hline
\end{tabular}

assays (alamarBlue assay and CFDA-AM assay), and luminometric assays (ATP assays) [49]. Previous studies have investigated plant extract activity against Giardia and used dye exclusion and colorimetric assays to count viable cells [33, 46, 50-58]. In this study, a luminometric assay was selected for the detection of viable Giardia trophozoites exposed to crude extracts and essential oils from $A$. conyzoides because it is more sensitive and less susceptible to artifacts than are other methods of testing viability [49]. Crude extracts of LW-P $(45.67 \mu \mathrm{g} / \mathrm{mL})$ and FP $(96.00 \mu \mathrm{g} / \mathrm{mL})$ exhibited the highest activity against G. duodenalis. Notably, ethanolic extracts of different plant parts and different colored flowers of $A$. conyzoides exhibited different levels of efficacy against Giardia. Rayan et al. [57] tested the activity of methanolic and aqueous Terminalia ferdinandiana fruit extracts against $G$. duodenalis and found the $\mathrm{IC}_{50}$ values of 704 (inactive) and 143 (active) $\mu \mathrm{g} / \mathrm{mL}$, respectively (lower efficacy than this study). Calzada et al. [52] tested in vitro activity of 26 plants against Giardia and found that Dorstenia contrajerva, Senna villosa, and Ruta chalepensis were showed high activity against Giardia, with $\mathrm{IC}_{50}$ values of $<38 \mu \mathrm{g} / \mathrm{mL}$. Compared with $\mathrm{IC}_{50}$ values reported in previous studies, high-to-moderate activities of crude extracts and essential oils were observed in this study [33, 46, 50-58].

In this study, the $\mathrm{IC}_{50}$ values of essential oils were slightly lower than those of crude extracts perhaps because of purer active compounds in essential oils when extracted by hydrodistillation. Moreover, a leaf decoction of $A$. conyzoides has been used to treat patients with diarrhea in Bangladesh [59]. The crude extracts may be more practical to use than are essential oils, particularly in remote areas and areas with high prevalence of parasitic infections. The solvent selected for extraction is important to avoid contamination and to ensure the safety of treatment. In this study, we did not test the cytotoxicity of tested extracts. However, a previous study has reported that leaf extract of $A$. conyzoides using hydroalcohol (ethanol 90: water 10) was not harmful when administered orally to rats [60], and the solvent used in that study was somewhat similar to the one used in this study.

The primary chemical components of LW-P and FP essential oils were chromenes, followed by sesquiterpenes and monoterpenes. Notably, FP essential oil contained many monoterpenes, which may have reduced its activity compared with LW-P essential oils in this study. Assumedly, monoterpenes have more analgesic properties than other chemical groups. Machado et al. [61] have reported that essential oils rich in monoterpenes (carvacrol) from Thymbra capitata and Origanum virens showed the greatest efficiency against G. duodenalis. However, this result is not consistent with previous reports because of differences in the main chemical components across monoterpene group. Essential oils from plants have been shown to exhibit anti-helminthic, anti-tumor, antiinflammatory, nematocidal, insecticidal, and antiparasitic activities [62-67]. These functions may be related to the diverse chemical components found in essential oils [68]. Two mechanisms of action of 

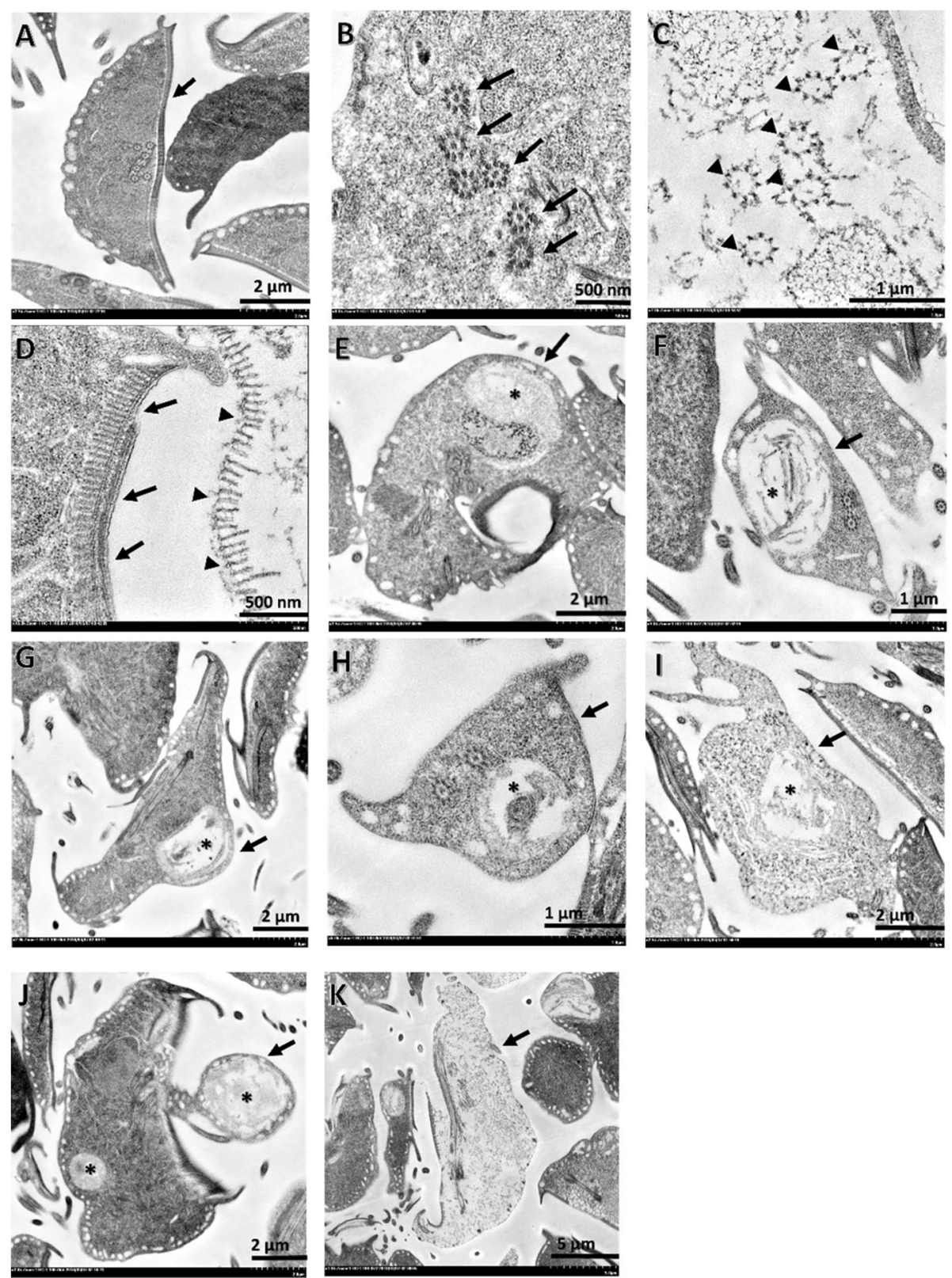

Fig. 2 Morphological changes in ultrastructure of Giardia exposed to crude extracts of Ageratum conyzoides (LW-P and FP): normal architecture of Giardia (a; arrow) and its flagella (b; arrow) compared with degenerated flagella and ventral discs (d: normal; arrow and degenerated: arrowhead); nucleolar changes (e; star); vacuolation (f-i; star); unusual shape (j; arrow); and chromatin loss (k; arrow) were observed

essential oils can explain their anti-parasitic activities: direct anti-parasitic action and immunomodulatory properties [62]. However, details of mechanisms underlying these actions of essential oils remain unknown [69].

TEM revealed that the ultrastructure of G. duodenalis trophozoits treated with or without crude extracts showed different internal structures between the two groups. Structural alterations including those in flagella, ventral discs, nuclei, cellular vacuoles, shapes, and chromatin were observed (Fig. 2). Crude extracts may have caused cell death by reducing the attachment ability by degenerating the flagella and ventral discs (Fig. 2c, d), which represent similar targets as those of commercial anti-Giardia drugs [70, 71]. These structures play a significant role in the attachment of protozoans to the surface of intestinal cells [72]. Similarly, nuclei showed altered shapes (Fig. 2e). The ultrastructure of $G$. duodenalis treated with or without essential oils warrant further investigation 
to clarify the significance of morphological changes in organelles.

\section{Conclusions}

LW-P and FP from A. conyzoides were more effective against Giardia than the other tested extracts. Thus, A. conyzoides may be a potential source of anti-Giardia drugs. Moreover, exposure to these extracts changed the ultrastructure of Giardia trophozoites, such as flagella and ventral discs, which are the structures targeted by commercial anti-Giardia drugs. Therefore, A. conyzoides extracts, particularly from LW-P and FP plants, warrant further investigation in terms of their efficacy and safety as giardiasis treatment.

\section{Supplementary information}

Supplementary information accompanies this paper at https://doi.org/10. 1186/s12906-020-2860-6.

\section{Additional file 1.}

\section{Abbreviations}

DMSO: Dimethyl sulfoxide; FP: Flowers of purple flowered plants; FW: Flowers of white flowered plants; FW-P: Flowers of white-purple flowered plants; GC-MS: Gas chromatography-mass spectrometry; I $\mathrm{C}_{50}$ : Half maximal inhibitory concentration; LP: Leaves of purple flowered plants; LW: Leaves of white flowered plants; LW-P: Leaves of white-purple flowered plants; TEM: Transmission electron microscopy

\section{Acknowledgments}

The authors are grateful to Dr. Siriluck Attrapadung for suggesting the experimental design. We thank Mrs. Keawmala Palakul for her help in collecting plants from the field.

\section{Authors' contributions}

$A P, J R, S A, K T, P S, N K$, and SP conceived experiments. AP and JR collected plants from field. AP, SA, KT, and SP performed laboratory sections. AP, SA, and SP analyzed and interpreted data and wrote the manuscript. All authors contributed, read, and approved the final version of the manuscript.

\section{Funding}

The study was supported by the Royal Golden Jubilee Ph.D. scholarship from the Thailand Research Fund (RGJ-TRF) and the French Government's contribution to the RGJ-Ph.D. programme but did not have any additional roles in the study design, data collection or analyses of this manuscript

\section{Availability of data and materials}

The datasets used and/or analyzed during the present study are available from the corresponding author on reasonable request.

\section{Ethics approval and consent to participate} Not applicable.

\section{Consent for publication}

Not applicable.

\section{Competing interests}

The authors declare that they have no competing interests.

\section{Author details}

'Department of Medical Entomology, Faculty of Tropical Medicine, Mahido University, Ratchawithi Road, Ratchathewi, Bangkok 10400, Thailand. ${ }^{2}$ Department of Tropical Pathology, Faculty of Tropical Medicine, Mahidol University, Ratchawithi Road, Ratchathewi, Bangkok 10400, Thailand.
${ }^{3}$ Department of Protozoology, Faculty of Tropical Medicine, Mahidol University, Ratchawithi Road, Ratchathewi, Bangkok 10400, Thailand.

Received: 22 February 2019 Accepted: 20 February 2020

Published online: 28 February 2020

\section{References}

1. Adam RD. Biology of Giardia lamblia. Clin Microbiol Rev. 2001;14:447-75

2. Feng Y, Xiao L. Zoonotic potential and molecular epidemiology of Giardia species and giardiasis. Clin Microbiol Rev. 2011;24:110-40.

3. Ryan U, Cacciò SM. Zoonotic potential of Giardia. Int J Parasitol. 2013:43: 943-56.

4. Einarsson E, Ma'ayeh S, Svärd SG. An up-date on Giardia and giardiasis. Curr Opin Microbiol. 2016;34:47-52.

5. Squire SA, Ryan U. Cryptosporidium and Giardia in Africa: current and future challenges. Parasit Vectors; 2017. https://doi.org/10.1186/s13071-017-2111y.

6. Boontanom P, Mungthin M, Tan-ariya P, Naaglor T, Leelayoova S. Epidemiology of giardiasis and genotypic characterization of Giardia duodenalis in preschool children of a rural community, Central Thailand. Trop Biomed. 2011;28:32-9.

7. Boontanom $\mathrm{P}$, Pipatsatitpong D, Tan-ariya $\mathrm{P}$, Mungthin $M$, Siripattanapipong $\mathrm{S}$, Naaglor T, et al. Incidence and risk factors of Giardia duodenalis infection in an orphanage, Thailand. Trop Biomed. 2014;31:525-33.

8. Kitvatanachai S, Rhongbutsri P. Intestinal parasitic infections in suburban government schools, LakHok subdistrict, Muang Pathum Thani, Thailand. Asian Pac J Trop Med. 2013;6:699-702.

9. Piangjai S, Sukontason K, Sukontason KL. Intestinal parasitic infections in hilltribe schoolchildren in Chiang Mai, northern Thailand. Southeast Asian J Trop Med Public Health. 2003;34:90-3.

10. Pothipak N, Srivilairit S, Pengruksa C, Faithong S, Haohan O, Chalermrut K, et al. Health status: malaria, anemia and intestinal parasitic infections on the Thai-Myanmar border. J Trop Med Parasitol. 2005;28:26-30.

11. Ratanapo S, Mungthin M, Soontrapa S, Faithed C, Siripattanappong S, Rangsin $\mathrm{R}$, et al. Multiple modes of transmission of giardiasis in primary schoolchildren of a rural community, Thailand. Am J Trop Med Hyg. 2008; 78:611-5.

12. Rhongbutsri $P$, Saichua $P$, Navaphongpaveen $K$, Taylor A, Leelawongtawongtawon R, Kitvatanachai S. Intestinal parasitic infections in students at a school for handicapped children in Khon Kaen province, Thailand. Thammasart Med J. 2010:10:406-10.

13. Saksirisampant W, Nuchprayoon S, Wiwanitkit V, Yenthakam S, Ampavasiri A. Intestinal parasitic infestations among children in an orphanage in Pathum Thani province. J Med Assoc Thail. 2003;86:S263-70.

14. Saksirisampant W, Prownebon J, Kanmamee P, Thaisom S, Yenthakam S, Nuchprayoon S. Prevalence of parasitism among students of the Karen HillTribe in Mae Chame district, Chiang Mai province, Thailand. J Med Assoc Thai. 2004;87:S278-83.

15. Saksirisampant $\mathbf{W}$, Boontanom $P$, Mungthin M, Tan-ariya $P$, Lamchuan D Siripattanapipong $\mathrm{S}$, et al. Prevalence of giardiasis and genotypic characterization of Giardia duodenalis in hilltribe children, Northern Thailand Trop Biomed. 2012;29:331-8.

16. Termmathurapoj S, Engkanun K, Naaglor T, Taamsri P, Areekul W, Leelayoova $\mathrm{S}$, et al. Cross-sectional study of intestinal protozoan infections in orphans and childcare workers at the Phayathai babies' home, Bangkok, Thailand. J Trop Med Parasitol. 2000;23:21-7.

17. Tungtrongchitr A, Chiworaporn C, Praewanich R, Radomyos P, Boitano JJ. The potential usefulness of the modified Kato thick smear technique in the detection of intestinal sarcocystosis during field surveys. Southeast Asian J Trop Med Public Health. 2007;38:232-8.

18. Waikagul J, Krudsood S, Radomyos P, Radomyos B, Chalemrut K, Jonsuksuntigul $P$, et al. A cross-sectional study of intestinal parasitic infections among schoolchildren in Nan province, northern Thailand. Southeast Asian J Trop Med Public Health. 2002;33:218-23.

19. Waree P, Polseela P, Pannarunothai S, Pipitgool V. The present situation of paragonimiasis in endemic area in Phitsanulok province. Southeast Asian J Trop Med Public Health. 2001;32:51-4.

20. Wongjindanon N, Suksrichavalit T, Subsutti W, Sarachart T, Worapisuttiwong $U$, Norramatha P. Current infection rate of Giardia lamblia in two provinces of Thailand. Southeast Asian J Trop Med Public Health. 2005;36:21-5. 
21. Faubert G. Immune response to Giardia duodenalis. Clin Microbiol Rev. 2000; 13:35-54.

22. Huang DB, White AC. An updated review on Cryptosporidium and Giardia. Gastroenterol Clin N Am. 2006;35:291-314.

23. Sahagun J, Clavel A, Goni P, Seral C, Llorente MT, Castillo FJ, et al. Correlation between the presence of symptoms and the Giardia duodenalis genotype. Eur J Clin Microbiol Infect Dis. 2008;27:81-3.

24. Hotez PJ, Brooker S, Bethony JM, Bottazzi ME, Loukas A, Xiao S. Hookworm infection. N Engl J Med. 2004;351:799-807.

25. Merchant RH, Shroff RC. The prevalence of HIV infection in children with extensive tuberculosis and chronic diarrhoea. AIDS Asia. 1996;3:21-3.

26. Feitosa G, Bandeira AC, Sampaio DP, Badaro R, Brites C. High prevalence of giardiasis and strongyloidiasis among HIV-infected patients in Bahia, Brazil. Braz J Infect Dis. 2001;5:339-44.

27. Joshi M, Chowdhary AS, Dalal PJ, Maniar JK. Parasitic diarrhoea in patients with AIDS. Natl Med J India. 2002;15:72-4.

28. Mohandas K, Sehgal R, Sud A, Malla N. Prevalence of intestinal parasitic pathogens in HIV-seropositive individuals in northern India. Jpn J Infect Dis. 2002;55:83-4.

29. Solaymani-Mohammadi S, Genkinger JM, Loffredo CA, Singer SM. A metaanalysis of the effectiveness of albendazole compared with metronidazole as treatments for infections with Giardia duodenalis. PLoS Negl Trop Dis. 2010;4:e682.

30. Shepherd R, Boreham PFL. Recent advances in the diagnosis and management of giardiasis. Scand J Gastroenterol. 1989;24:60-4.

31. Upcroft JA, Campbell RW, Benakli K, Upcroft P, Vanelle P. Efficacy of new 5 nitroimidazoles against metronidazole-susceptible and-resistant Giardia, Trichomonas, and Entamoeba spp. Antimicrob Agents Chemother. 1999;43: 73-6.

32. Upcroft P, Upcroft JA. Drug targets and mechanisms of resistance in the anaerobic protozoa. Clin Microbiol Rev. 2001;14:150-64

33. de Almeida I, Alviano DS, Vieira DP, Alves PB, Blank AF, Lopes AH, et al. Antigiardial activity of Ocimum basilicum essential oil. Parasitol Res. 2007; 101:443-52.

34. The Plant List. Published on the internet, version 1.1. 2013. http://www. theplantlist.org. Accessed 1 Jan 2020.

35. Taleb-Contini SH, Salvador MJ, Balanco JM, Albuquerque S, de Oliveira DC. Antiprotozoal effect of crude extracts and flavonoids isolated from Chromolaena hirsuta (Asteraceae). Phytother Res. 2004;18:250-4.

36. Elufioye T, Agbedahunsi J. Antimalarial activities of Tithonia diversifolia (Asteraceae) and Crossopteryx febrifuga (Rubiaceae) on mice in vivo. J Ethnopharmacol. 2004;93:167-71.

37. Idowu O, Soniran O, Ajana O, Aworinde D. Ethnobotanical survey of antimalarial plants used in Ogun state, Southwest Nigeria. Afr J Pharm Pharmacol. 2010:4:55-60.

38. Ukpai OM, Amaechi EC. Evaluation of in vivo antimalarial activity of the ethanolic leaf extracts of Chromolaena odorata and Cymbopogon citratus in mice. Niger J Biotechnol. 2012;24:27-34

39. Ming LC. Ageratum conyzoides: a tropical source of medicinal and agricultural products. In: Janick J, editor. Perspectives on new crops and new uses, Alexandria. USA: ASHS Press; 1999. p. 469-73.

40. Kong $\mathrm{CH}$. Allelochemicals from Ageratum conyzoides $\mathrm{L}$. and Oryza sativa $\mathrm{L}$. and their effects on related pathogens. In: Inderjit MKG, editor. Allelochemicals, Biological control of plant pathogens and diseases. Netherlands: Springer; 2006. p. 193-6.

41. Okunade AL. Ageratum conyzoides L.(Asteraceae). Fitoterapia. 2002;73:1-16.

42. Chah KF, Eze CA, Emuelosi CE, Esimone CO. Antibacterial and wound healing properties of methanolic extracts of some Nigerian medicinal plants. J Ethnopharmacol. 2006;104:164-7.

43. Diallo A, Eklu-Gadegbeku K, Amegbor K, Agbonon A, Aklikokou K, Creppy E, et al. In vivo and in vitro toxicological evaluation of the hydroalcoholic leaf extract of Ageratum conyzoides L.(Asteraceae). J Ethnopharmacol. 2014;155: 1214-8.

44. Sultana M, Verma PK, Raina R, Prawez S, Dar MA. Quantitative analysis of total phenolic, flavonoids and tannin contents in acetone and $n$-hexane extracts of Ageratum conyzoides. Int J ChemTech Res. 2012;4:996-9.

45. Horie $T$, Tominaga $H$, Kawamura Y. Revised structure of a natural flavone from Ageratum conyzoides. Phytochemistry. 1993;32:1076-7.

46. Wabo Poné J, Fossi Tankoua O, Yondo J, Komtangi MC, Mbida M, Bilong Bilong CF. The in vitro effects of aqueous and ethanolic extracts of the leaves of Ageratum conyzoides (Asteraceae) on three life cycle stages of the parasitic nematode Heligmosomoides bakeri (Nematoda: Heligmosomatidae). Vet Med Int. 2011. https://doi.org/10.4061/2011/140293.

47. Keister DB. Axenic culture of Giardia lamblia in TYI-S-33 medium supplemented with bile. Trans R Soc Trop Med Hyg. 1983;77:487-8.

48. Amaral FMM, Ribeiro MNS, Barbosa-Filho JM, Reis AS, Nascimento FRF, Macedo RO. Plants and chemical constituents with giardicidal activity. Rev bras farmacogn. 2006;16:696-720.

49. Aslantürk ÖS. In Vitro Cytotoxicity and Cell Viability Assays: Principles, Advantages, and Disadvantages. In Genotoxicity-A Predictable Risk to Our Actual World. IntechOpen; 2017. p. 1-17.

50. Harris JC, Plummer S, Turner MP, Lloyd D. The microaerophilic flagellate Giardia intestinalis: Allium sativum (garlic) is an effective antigiardial. Microbiol. 2000;146:3119-27.

51. Gadelha AP, Vidal F, Castro TM, Lopes CS, Albarello N, Coelho MG, et al. Susceptibility of Giardia lamblia to Hovenia dulcis extracts. Parasitol Res. 2005;97:399-407.

52. Calzada F, Yepez-Mulia L, Aguilar A. In vitro susceptibility of Entamoeba histolytica and Giardia lamblia to plants used in Mexican traditional medicine for the treatment of gastrointestinal disorders. J Ethnopharmacol. 2006;108:367-70.

53. Moon T, Wilkinson JM, Cavanagh HM. Antiparasitic activity of two Lavandula essential oils against Giardia duodenalis, Trichomonas vaginalis and Hexamita inflata. Parasitol Res. 2006:99:722-8.

54. Barbosa E, Calzada F, Campos R. In vivo antigiardial activity of three flavonoids isolated of some medicinal plants used in Mexican traditional medicine for the treatment of diarrhea. J Ethnopharmacol. 2007;109:552-4.

55. Vidal F, Vidal JC, Gadelha AP, Lopes C, Coelho M, Monteiro-Leal L. Giardia lamblia: the effects of extracts and fractions from Mentha x piperita Lin. (Lamiaceae) on trophozoites. Exp Parasitol. 2007;115:25-31.

56. Neiva VA, Ribeiro MNS, Nascimento FRF, Cartágenes MSS, Coutinho-Moraes DF, Amaral FMM. Plant species used in giardiasis treatment: ethnopharmacology and in vitro evaluation of anti-Giardia activity. Rev Bras Farmacogn. 2014;24:215-24.

57. Rayan P, Matthews B, McDonnell PA, Cock IE. Terminalia ferdinandiana extracts as inhibitors of Giardia duodenalis proliferation: a new treatment for giardiasis. Parasitol Res. 2015;114:2611-20.

58. Pecková R, Doležal K, Sak B, Květoňová D, Kváč M, Nurcahyo W, et al. Effect of Piper betle on Giardia intestinalis infection in vivo. Exp Parasitol. 2018;184: 39-45.

59. Rahmatullah M, Mahmud AA, Rahman MA, Uddin MF, Hasan M, Khatun MA, et al. An ethnomedicinal survey conducted amongst folk medicinal practitioners in the two southern districts of Noakhali and Feni, Bangladesh. Am-Eur J Sustain Agric. 2011;5:115-31.

60. Diallo A, Eklu-Gadegkeku K, Agbonon A, Aklikokou K, Creppy EE, Gbeassor M. Acute and sub-chronic (28-day) oral toxicity studies of hydroalcohol leaf extract of Ageratum conyzoides L (Asteraceae). Trop J Pharmaceut Res. 2010; 9:463-7.

61. Machado M, Dinis AM, Salgueiro L, Cavaleiro C, Custódio JB, Sousa MC. AntiGiardia activity of phenolic-rich essential oils: effects of Thymbra capitata, Origanum virens, Thymus zygis subsp. sylvestris, and Lippia graveolens on trophozoites growth, viability, adherence, and ultrastructure. Parasitol Res. 2010;106:1205-15.

62. Antony JP, Fyfe L, Smith H. Plant active components-a resource for antiparasitic agents? Trends Parasitol. 2005;21:462-8.

63. Kamboj A, Saluja AK. Ageratum conyzoides L.: a review on its phytochemical and pharmacological profile. Int J Green Pharm. 2008;2:59-68.

64. Bouda H, Tapondjou LA, Fontem DA, Gumedzoe MYD. Effect of essential oils from leaves of Ageratum conyzoides, Lantana camara and Chromolaena odorata on the mortality of Sitophilus zeamais (Coleoptera, curculionidae). J Stored Prod Res. 2001;37:103-9

65. Lima RK, Cardoso MD, Moraes JC, Andrade MA, Melo BA, Rodrigues VG. Chemical characterization and insecticidal activity of the essential oil leaves of Ageratum conyzoides L. on fall armyworm Spodoptera frugiperda (Smith 1797) (Lepidoptera: Noctuidae). Biosci J. 2010;26:1-5.

66. Moura AC, Silva EL, Fraga MC, Wanderley AG, Afiatpour P, Maia MB. Antiinflammatory and chronic toxicity study of the leaves of Ageratum conyzoides L. in rats. Phytomedicine. 2005;12:138-42.

67. Momesso LS, de Moura RMX, Constantino DHJ. Antitumoral activity of Ageratum conyzoides L. (Asteraceae). Rev Bras Farmacogn. 2009;19:660-3.

68. Mahmoud SS, Croteau RB. Strategies for transgenic manipulation of monoterpene biosynthesis in plants. Trends Parasitol. 2002;7:366-73. 
69. Monzote L, Alarcón O, Setzer WN. Antiprotozoal activity of essential oils. Agric conspec. 2012;77:167-75

70. Campanati L, Gadelha AP, Monteiro-Leal LH. Electron and video-light microscopy analysis of the in vitro eVects of pyrantel pamoate on Giardia lamblia. Exp Parasitol. 2001;97:9-14.

71. Campanati L, Monteiro-Leal LH. The eVects of the antiprotozoal drugs metronidazole and furazolidone on trophozoites of Giardia lamblia (P strain). Parasitol Res. 2002;88:80-5.

72. Campanati L, Holloschi A, Troster H, Spring H, Souza WD, Monteiro-Leal LH. Video-microscopy observations of fast dynamic processes in the protozoon Giardia lamblia. Cell Motil Cytoskeleton. 2002;51:213-24.

\section{Publisher's Note}

Springer Nature remains neutral with regard to jurisdictional claims in published maps and institutional affiliations.

Ready to submit your research? Choose BMC and benefit from:

- fast, convenient online submission

- thorough peer review by experienced researchers in your field

- rapid publication on acceptance

- support for research data, including large and complex data types

- gold Open Access which fosters wider collaboration and increased citations

- maximum visibility for your research: over $100 \mathrm{M}$ website views per year

At BMC, research is always in progress.

Learn more biomedcentral.com/submissions 